\title{
古日記天候記録による琵琶湖歴史渴水の復元 RECONSTRUCTION OF HISTORICAL DROUGHTS IN LAKE BIWA AREA USING HISTORICAL DAILY WEATHER RECORDS
}

\author{
庄 建治朗 1 ・冨永 晃宏 2 \\ Kenjiro SHO and Akihiro TOMINAGA \\ 1 正会員 工修 名古屋工業大学助手 工学部システムマネジメント工学科 \\ （广466-8555 名古屋市昭和区御器所町） \\ 2 正会員 工博 名古屋工業大学教授 工学部社会開発工学科（广466-8555 名古屋市昭和区御器所町）
}

\begin{abstract}
Daily weather records of old diaries are useful for investigating hydrological environment in historical days. In this paper, we collected daily weather records from 8 old diaries of $18-20^{\text {th }}$ centuries in Lake Biwa area and attempted to use them for evaluating the intensity of historical droughts in Lake Biwa area. Annual maximum duration of continuous no-rainy days and annual minimum PI (Precipitation Index) for 30, 60, 90 days, which is calculated by summing up the number of rainy days for $30,60,90$ days with the weights of 'small rain : rain : heavy rain $=1: 2: 5$,' were calculated for each diary, and the intensity of some serious drought were quantitatively evaluated.
\end{abstract}

Key Words : Historical droughts of Lake Biwa, old diaries, daily weather records, Precipitation Index

\section{1. はじめに}

近年、地球規模の気候変動とも関連して水資源の安定 確保がますます重要な課題となってきている。適切な利 水計画を立てるためにも、過去に起こった渴水について 正確な知見を得ることは重要である。日本で気象観測が 開始されるのは明治に入ってからであり、観測データが 得られるのは長くて近年 100 年分程度であるが、気候変 動にはより長期の周期性を指摘する向きもあり、そうし た長期的な変動傾向を検討するためには明治以前の情報 を何らかの方法で得る必要がある。

琵琶湖流域については、彦根に滋賀県立彦根測候所 （現在の彦根地方気象台）が設置され気象観測が開始さ れるのは 1893 年 (明治 26) 10 月であり、それ以前にお ける渴水や洪水等の水文・気象現象については、古文書 等に残された記事を手懸かりにするほかない。例えば江 戸時代中期以降の大旱䰠としては、明和 7 年 (1770)、 文政 4 年 (1821) 、嘉永 6 年 (1853) 等が著名であるが、 古記録には「湖水一丈減水」「百日間雨無し」「松七分 通リ枯ル」等といった記述はあるものの、こうした情報 から渴水の規模を客観的に表すのは困難である。

著者らは、琵琶湖流域における近世以降の水文環境を 知る手懸かりとするため、流域各地に散在する古日記か
ら天候記録を収集整理する作業を続けている。古気候・ 古環境を復元する手段としては、他に樹木年輪や水床コ ア等も用いられるが、日本の近世の気候復元の資料とし ては文献記録が最も充実している。とりわけ古日記の天 候記録は、天気という気象現象そのものに関する記録が 日単位で連続的に得られることから、渴水という長期間 持続する現象を復元するには最も有力な資料になると考 えられる。こうした資料は当然ながら時代が下るほど現 在に残される記録の量は増大し、天保年間（1830～40 頃）以降ともなると量的にかなり充実する様になる。

本研究では、江戸時代中期 (享保年間) 以降を対象と し、歴史天候記録を用いて古記録に残る琵琶湖の歴史渇 水の規模を定量的に表すことを試みる。

\section{2. 歴史天候記録の整理}

\section{（1）琵琶湖流域の古日記天候記録}

著者らがこれまでに琵琶湖流域各地から収集した古日 記は、以下の通り 8 史料のべ約 283 年分である。これら の記録は現代に近くなるほど情報量が増大し、江戸時代 末期には幾つかの史料の天候記録が重複しているが、そ の前の時期にはどの史料にも天候記録のない空白期間が 存在する。各史料の天候記載地点の位置図を 図-1 に、 
天候記録が得られる期間を 図-2 に示す。

\section{a）知則日記（彦根市立図書館所蔵）}

彦根藩の藩士知則の 46 歳より 83 歳に至る迄の私的な 日記。記録は享保 16 年 (1731) から明和 5 年 (1768) 迄 38 年間に亘り、その間欠落は比較的少ない。毎日の天 気変化が時間経過とともにかなり詳細に記されている。

\section{b）小室藩日記（東浅井郡浅井町佐治重宗氏所蔵）}

現在の東浅井郡浅井町に所在した小室藩小堀氏の主に 日常の藩政を記した日記。天候記載は延享 3 年 (1746) から小室藩が改易となる前年の天明 7 年 (1787) 迄 42 年 間ほぼ連続しており、久測は非常に少ない。一日の天気 概況が 1 語て簡略に記されている場合が多い。

c）市田清兵衛文書「日記」（滋賀大学経済学部附属史 料館所蔵)

近江八幡の呉服・雑貨商市田清兵衛家の数代に亘る日 記。文化元年 (1804) から明治中頃まで 100 年近くに及

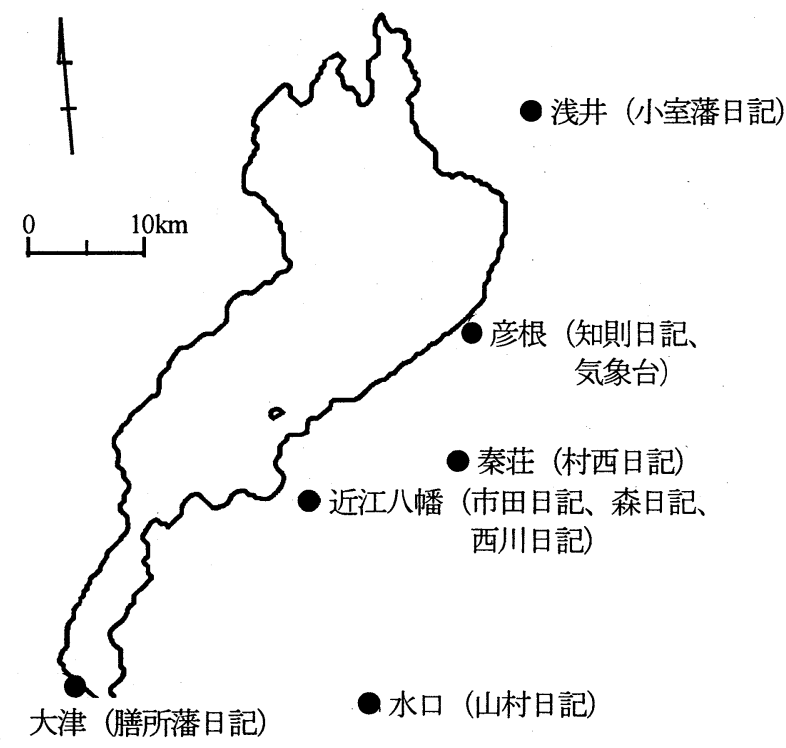

図-1 琵琶湖流域歴史天候記録位置図
ぶ天候記録が得られる。但し、特に期間の前半では記録 者は毎年のように上州高崎の支店に出張しており、その 間数力月間は旅先の天候しか判らない。また京、名古屋 等へもしばしば出張している。

d）山村日記（水口町立水口図書館所蔵）

現在の甲賀郡水口町に藩庁を置いた水口藩の掛屋 (金 融業) で大庄屋を勤めた山村家の当主 3 代に亘る日記。 文化 13 年 (1816) から明治 9 年 (1876) 迄 61 年間に亘り 1 年 1 冊ずつ書き続けられたと見られるが、その中には 逸失したものもあり、現存するのは 44 年分である。天 気が継続的に記される様になるのは文政 10 年 (1827) 以 降であり、途中数年分の欠落がある。

\section{e) 膳所藩史料（滋賀県立図書館所蔵）}

現在の大津市に位置した膳所藩の藩政に関する記録。 元禄 3 年 (1690) から明治初頭まで約 2 世紀にわたる膨 大な記録が 270 余巻に䌕められている。日記中に天気が 継続的に記録される様になるのは天保 14 年以降である が、途中欠落していたり、天気の記載がない場合も多い。 一日の天気概況が 1 語で簡略に記されている。

\section{f）森五良兵衛日記（近江八幡市立資料館所蔵）}

近江八幡の呉服太物商森五良兵衛家の数代に亘る日記。 安永元年 (1772) から明治中頃まで 100 年以上に亘って 記録されていたと見られるが、現在残存し、連続した天 候記録が得られるのは天保 14 年 (1843) から明治元年 （1868）迄である。毎日の天気概況が朝、昼、夜に分け て記されており、詳細な天気変化を知ることができる。

\section{g）西川伝右衛門文書（滋賀大学経済学部附属史料館所} 蔵)

近江八幡の商人西川伝右衛門家の日記。1886 年 (明治 19）から 1912 年 (明治 45) までの記録があり、この時期 には既に気象観測が開始されているため、古日記天候記 録と気象データとの対応関係を検証するのに利用できる。

h）村西文書（滋賀大学経済学部附属史料館所蔵）

秦荘の商人村西茂左衛門の日記。西川伝右衛門日記と

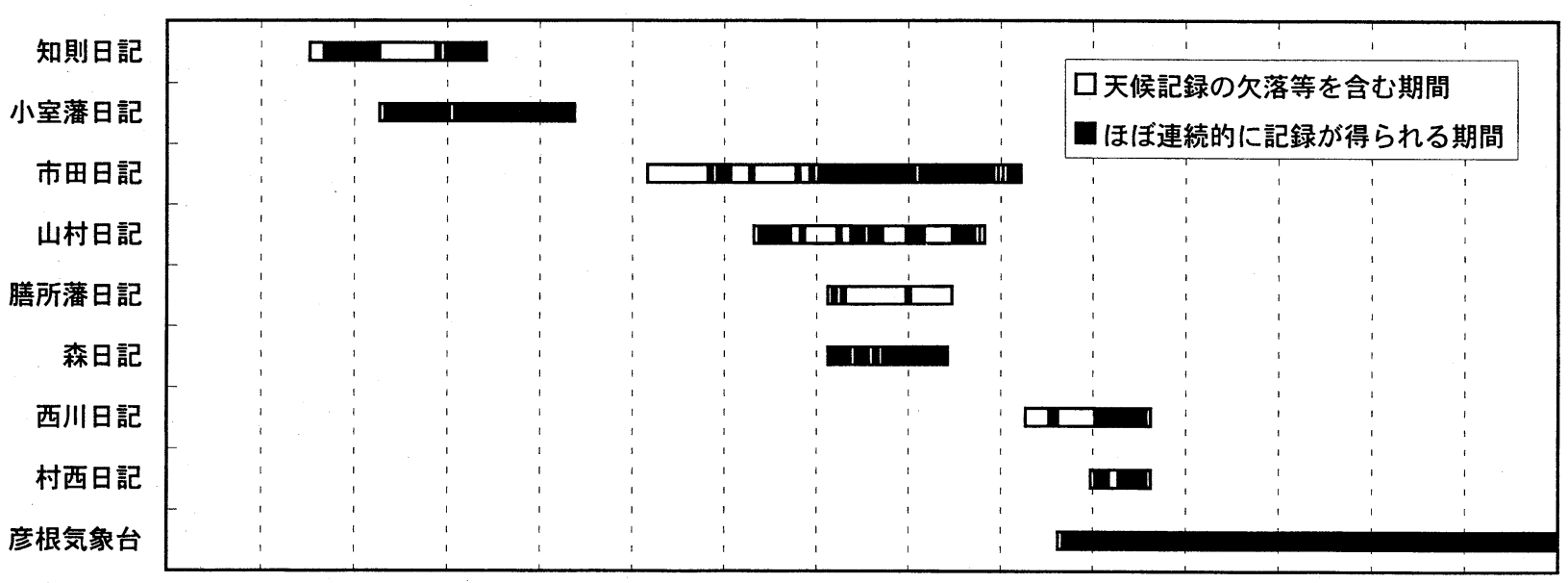


同じく明治時代の天候記録が得られる。

\section{（2）代表天気の抽出}

これらの古日記は、当然それぞれ記録者も記録のつけ られた地点も異なり、天候の記載方法も様々である。

「晴」「雨」等、その日の天気概況を簡潔に記したもの もあれば、1 日の天気変化を降雨の強弱や風向、寒暖等 まで含め時間経過とともに詳細に記したものもある。こ うした記録者の主観を含む定性的な記録をできるだけ定 量的・客観的に扱えるようにするため、まず前節で収集 した古日記から毎日の天候記載部分を取り出し、その記 述に応じて次の 11 種類の代表天気に分類した。但し、 同じ日に異なる天候記述が並列的に記されている場合に は、より悪天と考えられる方 (或いはより出現頻度が低 いと考えられる方）を採用することにした。

快晴 - ・ ・快晴、美晴、上天気、等

晴 ‥・晴、晴天、天晴、天気、天気よし、等
曇 …曇、曇天、天陰、等

小雨 . . 少雨、少雨、時雨、夕立、白雨、折々雨、 はらはら雨、等 (一時的な降雨を含む)

雨 $\cdots$. 雨、雨天、降、等

終日雨・・・終日雨降、昼夜降続、等

大雨・・大雨、強雨、等

小雪・ ・雪、少々雪、らららら雪、等

雪 ...雪、雪降、等

大雪. . . 大雪、等

その他・・䨌、霞、霨、等

図-3 は、各記録について代表天気の構成比率を 10 年 間毎に集計して表したものである。なお、これらのデー 夕を現代に接続するため、1894 年以降については彦根 地方気象台の降水量・雲量データをもとに代表天気を作 成した。即ち、西川日記及び村西日記の観測データと重 複する期間について、代表天気「小雨」「雨」「大雨」に 対応する日降水量の平均值を調べたところ、西川日記で
a) 知則日記
c) 市田日記

$100 \%$
$80 \%$
$60 \%$
$40 \%$
$20 \%$
$0 \%$
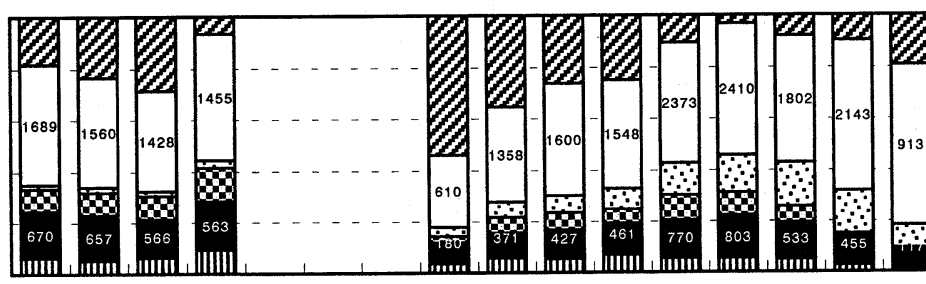

四欠落等

口晴・快晴

回罟

回小雨

b) 小室藩日記

d) 山村日記

-大雨

而雪・その他

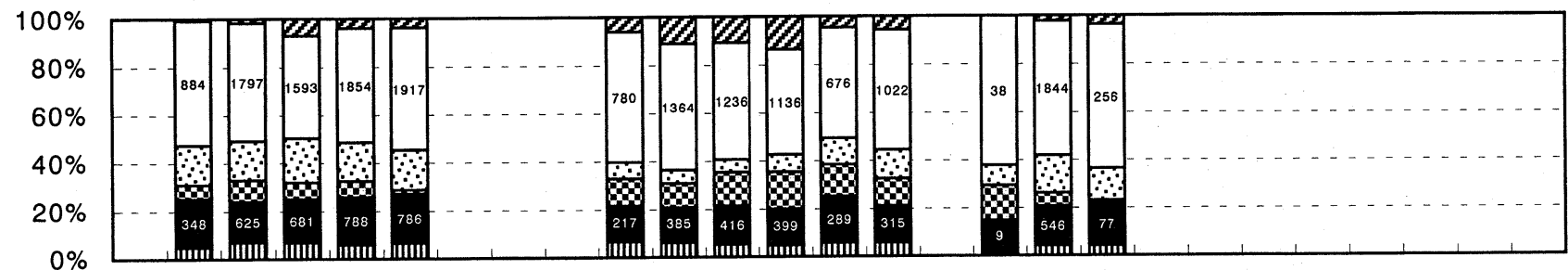

e) 膳所藩日記 $\quad g$ ) 西川日記

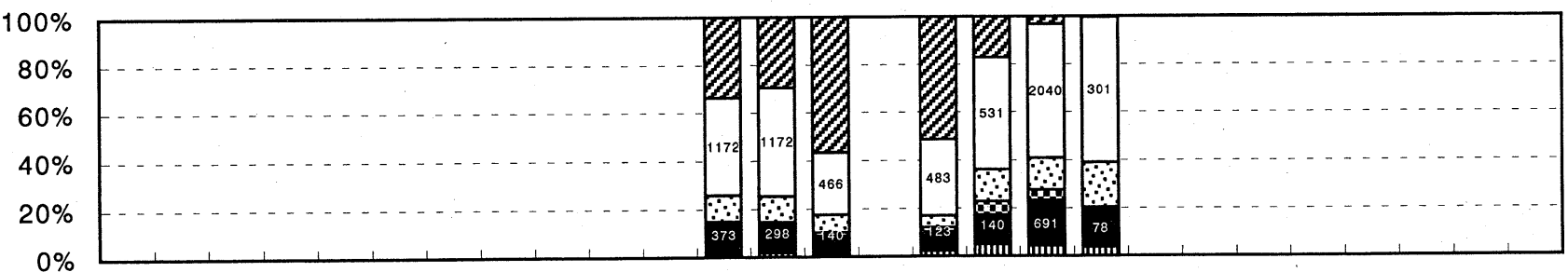

f) 森日記

i) 彦根気像台

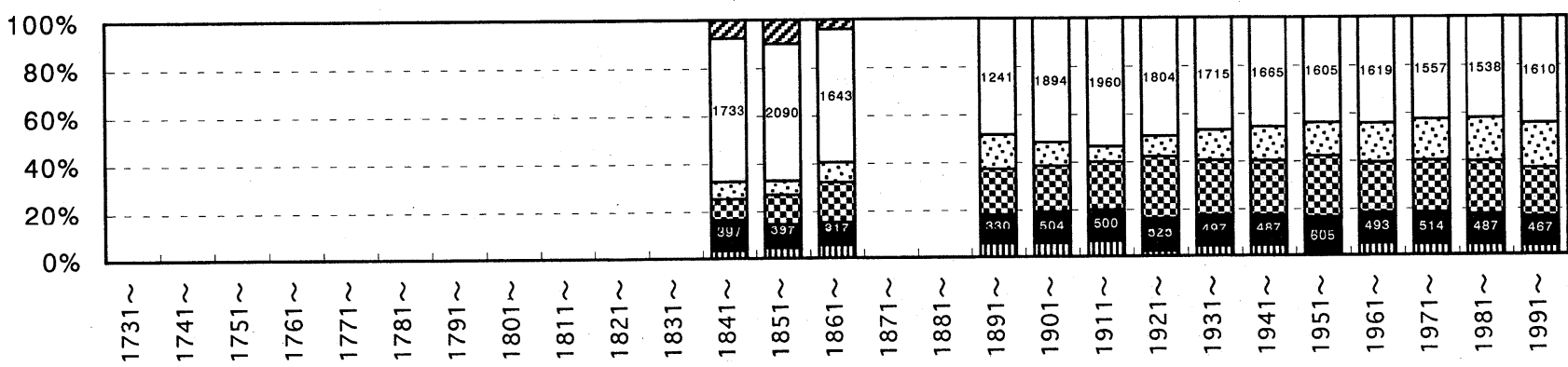

図-3 各日記の代表天気の構成比率（グラフ中の数字は標本日数） 
はそれぞれ $6.4 \mathrm{~mm} 、 14.1 \mathrm{~mm} 、 31.6 \mathrm{~mm}$ 、村西日記ではそ れぞれ $5.9 \mathrm{~mm} 、 15.3 \mathrm{~mm} 、 42.9 \mathrm{~mm}$ となったことから、こ こでよ気象台等でよく用いられる区分、日降水量 $30 \mathrm{~mm}$ 以上、 $10 \mathrm{~mm}$ 以上、 $1 \mathrm{~mm}$ 以上にそれぞれ「大雨」「雨」 「小雨」を割り当てた。次に代表天気「快晴」「晴」 「㬝」と雲量のデータを比較してみたが、その対応関係 はあまり明瞭でなかったため、ここでも気象台の区分を 利用し、日降水量 $1 \mathrm{~mm}$ 末満の場合には日平均雲量 8.5 以上に「最」、1.5 以上に「晴」、1.5 未満に「快晴」を 割り当てることにした。これらも 10 年間毎に集計して 図-3 に付け加えた。図-3 を見ると、同一の期間でも史 料によってかなり代表天気の構成比が異なる場合がある。 これは、史料によって天候の観測された地点が異なるた めとも考えられるが、記録者による天候の判別基準や記 載方法の違いも反映していると考えられる。

\section{3. 歴史渇水の評価}

本章では、前章で整理した天候記録を用い、次に示す 2 つの指標によって江戸時代中期以降の渴水規模の復元 を試みる。なお、明治 5 年 (1872) 以前の日記の日付に. は旧暦 (太陰太陽暦) が使用されているが、以後では全 て新暦 (グレゴリオ暦) に変換した上で使用する。

\section{(1) 連続無降雨日数}

毎日の天気の情報から渴水の強さを評価する指標とし て、ます連続無降雨日数を用いる。代表天気「快晴」 「晴」「曇」の日が最も長く連続する期間を年毎に求め、 その経年変化をグラフに表した (図-4 a))。大きな值 をとる年ほど雨の降らない日が連続し、渴水が深刻だっ たということになる。なお、天候記録が欠落している日 は降雨が無かったものと見なすが、期間中に欠測が 6 日 以上含まれる場合には連続無降雨日数の計算対象から除 くことにする。図より、渴水時には 30 日程度全く降雨 のない日が連続することがわかるが、中には他と比べて 極端に大きい值を示す場合がある。これは、期間中の降 雨を記録者が見落としたことによって連続無降雨日数が 実際よりも大きい值になったという可能性も考えられる。 特に短時間・小規模な降雨の場合には、それが記録に留 められるかどうかは記録者に大きく依存すると考えられ るため、次に無降雨に「小雨」まで含めることとし、代 表天気「快晴」「晴」「曇」「小雨」の連続する日数の最 大値を年毎に求めた（図-4 b)）。小雨まで含めると渴 水時には 40 日以上も無降雨 (小雨以下) 状態が続くこと がわかるが、この場合にも記録によって值が極端に大き い場合があり、やはり記録者による降雨の見落としが影 響している可能性がある。

\section{表-1 江戸時代中期以降の顕著な渇水事例}

\begin{tabular}{|c|c|c|c|c||c|c|c|c|c|}
\hline \multicolumn{3}{|c||}{ 年最大連続 小小雨」 以下数 } & \multicolumn{5}{|c|}{ 基淮化年最小 60 日間 PI } \\
\hline 年 & 月 & 日 & 日数 & 史料名 & 年 & 月 & 日 & PI & 史料名 \\
\hline 1882 & 5 & 23 & 89 & 市田日記 & 1882 & 5 & 23 & 0.0 & 市田日記 \\
1853 & 6 & 25 & 81 & 森日記 & 1883 & 4 & 9 & 0.0 & 市田日記 \\
1883 & 4 & 9 & 75 & 市田日記 & 1845 & 10 & 21 & 2.8 & 森日記 \\
1860 & 6 & 30 & 69 & 森日記 & 1871 & 7 & 7 & 4.1 & 市田日記 \\
1853 & 7 & 8 & 68 & 市田日記 & 1853 & 6 & 25 & 4.2 & 森日記 \\
1832 & 7 & 15 & 67 & 山村日記 & 1858 & 10 & 24 & 5.0 & 膳所藩日記 \\
1858 & 2 & 5 & 63 & 森日記 & 1853 & 7 & 8 & 5.2 & 市田日記 \\
1864 & 7 & 9 & 62 & 森日記 & 1876 & 7 & 7 & 5.3 & 市田日記 \\
1903 & 7 & 24 & 61 & 村西日記 & 1846 & 7 & 5 & 5.6 & 森日記 \\
1843 & 7 & 13 & 59 & 市田日記 & 1864 & 7 & 11 & 6.6 & 市田日記 \\
1843 & 7 & 19 & 57 & 山村日記 & 1910 & 11 & 11 & 7.0 & 村西日記 \\
1845 & 10 & 24 & 57 & 森日記 & 1856 & 1 & 1 & 8.3 & 森日記 \\
1909 & 7 & 6 & 57 & 村西日記 & 1909 & 7 & 6 & 8.4 & 村西日記 \\
1770 & 7 & 23 & 56 & 小室藩日記 & 1994 & 7 & 9 & 9.0 & 彦根気象台 \\
1844 & 7 & 16 & 56 & 森日記 & 2000 & 6 & 29 & 9.0 & 彦根気象台 \\
1739 & 7 & 24 & 55 & 知則日記 & 1856 & 7 & 10 & 9.2 & 市田日記 \\
1852 & 6 & 30 & 54 & 山村日記 & 1748 & 7 & 1 & 9.6 & 小室藩日記 \\
1846 & 7 & 5 & 54 & 森日記 & 1866 & 10 & 6 & 9.7 & 森日記 \\
1859 & 9 & 9 & 54 & 森日記 & 1903 & 7 & 24 & 9.8 & 村西日記 \\
1858 & 10 & 24 & 52 & 膳所藩日記 & 1853 & 6 & 29 & 10.0 & 膳所藩日記 \\
\hline
\end{tabular}


a) 年最大連続無降雨日数

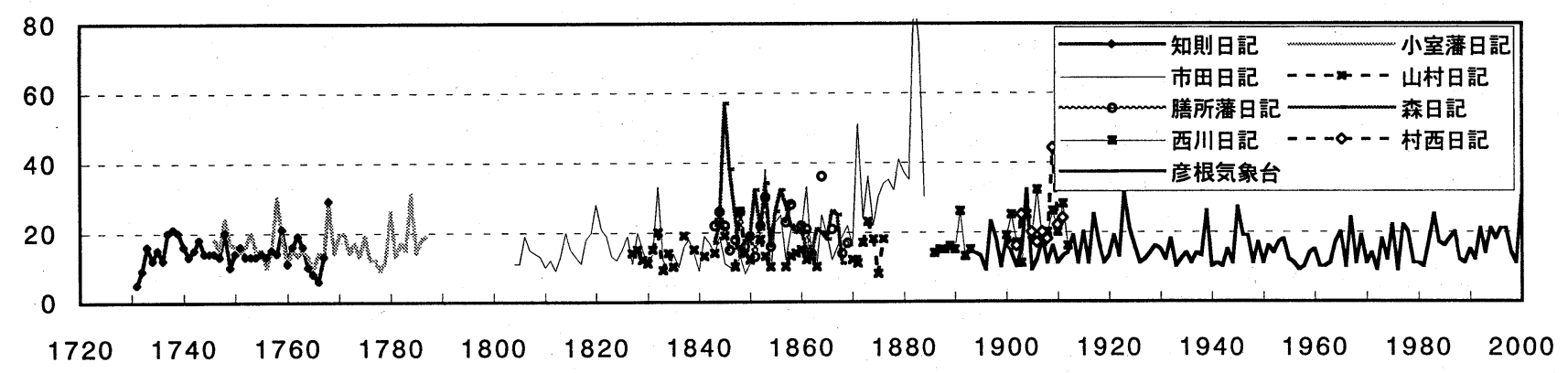

b) 年最大連続「小雨」以下日数

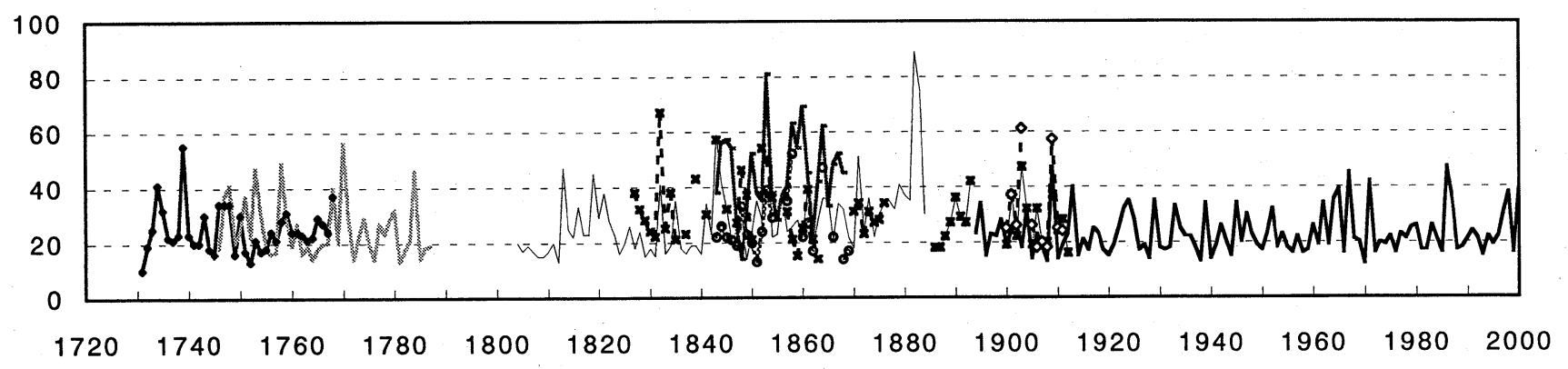

図-4 年最大連続無降雨日数

a) 基準化年最小30日間PI

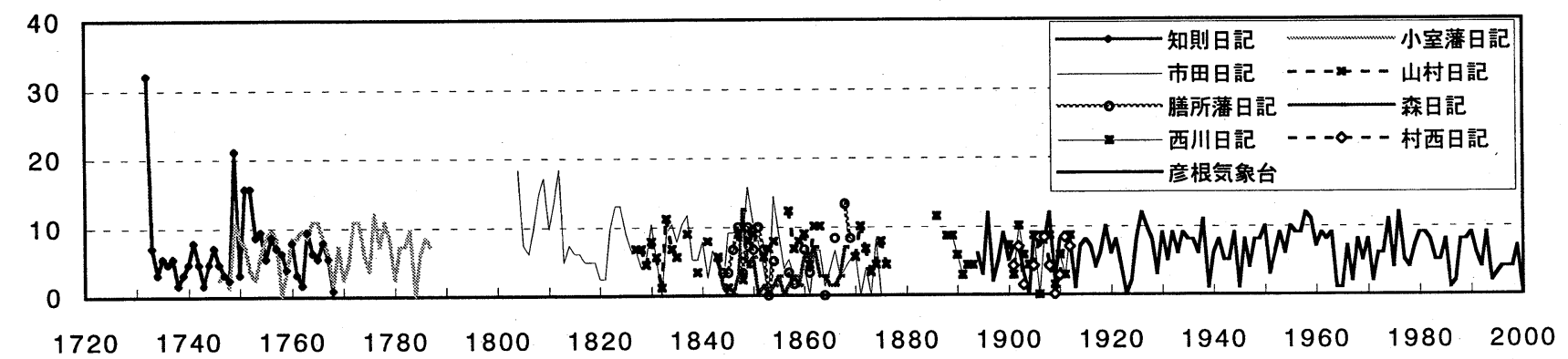

b) 基準化年最小 60 日間PI

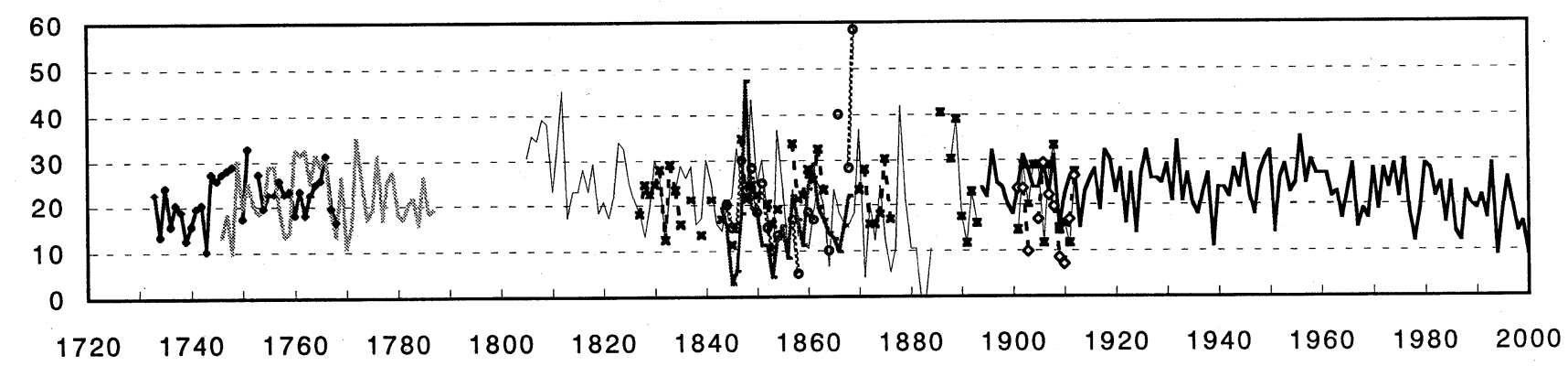

c) 基準化年最小 90 日間PI

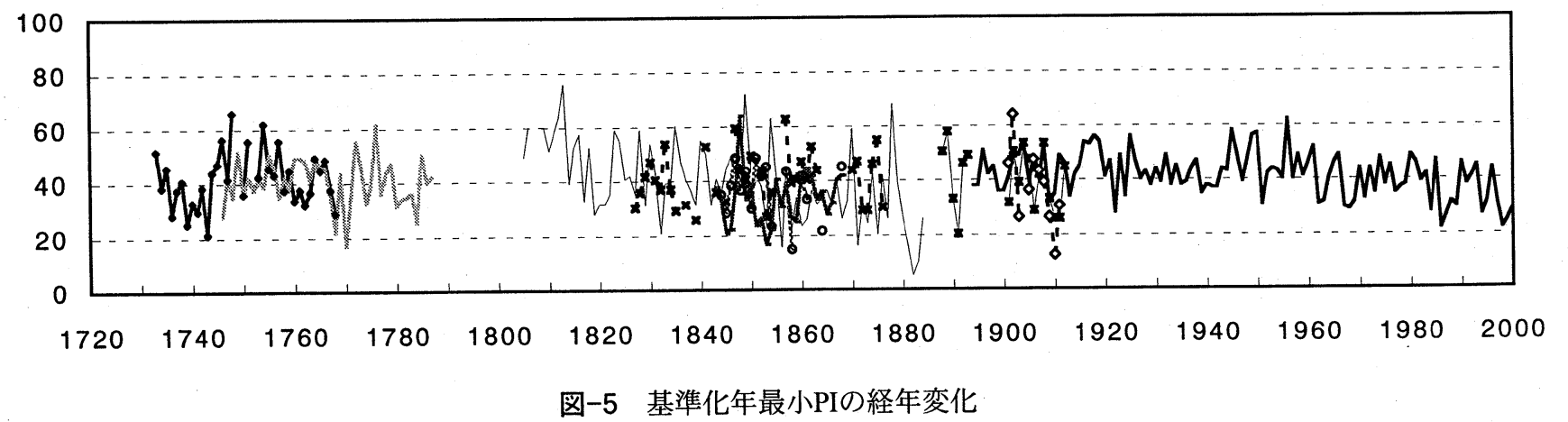




\section{（2）降水量指数 (PI) による評価}

前節で見たように、連続無降雨日数 (小雨以下日数) によって渴水の強さを評価する場合、記録者による降雨 の見落としや記載漏れが結果に大きな影響を及ぼすこと があるため、もう一つ別の指標で渴水強度を評価するこ とを試みる。

歴史天候記録から知り得る降雨に関する情報としては、 まずは降ったか降らなかったかの情報であるが、降雨が あった場合には、その時間経過や強弱に関する定性的な 記録が得られる場合も多い。吉村 ${ }^{5)}$ は、「小雨」「雨」

「大雨」にそれぞれ 1、2、5 の重率をつけてある程度以 上の長さの期間にわたって降雨日数を積算すると、その 值が同じ期間の総降雨量とよい対応を示すことを見出し た。これをPI (Precipitation Index, 降水量指数) という。 ここでもこの手法を援用し、代表天気「小雨」（「小雪」 も含む)に に、「雨」（「雪」等も含む）に2、「大雨」又 は「終日雨」（「大雪」も含む）に 5 の重率をつけて、任 意の $30 、 60 、 90$ 日間の積算值をとり、その值が 1 年で 最小となる期間を年毎に求めた。この值が小さいほどそ の期間中の雨が少なく、渴水が深刻だったことになる。 なお、天候記録が欠落している日は重率を０方するが、 欠測の日数が期間の 6 分の 1 (30 日なら 5 日、60日な ら 10 日、90 日なら 15 日）を超える場合には計算対象か ら除くことにする。さらに、「小雨」「大雨」等の判定 基準や記載の仕方は記録者によって異なると考えられる ため、異なる日記間で PI を比較するためにはこの条件 の違いを取り除く必要がある。そのためにここでは、史 料毎に (同じ史料でも途中で記録者が交代したことが明 らかな場合にはその記録者毎に）全期間を通しての PI の平均值が等しくなるよう（この場合は彦根気象台と同 じになるよう) PI に適当な定数を乗じ、基準化を行うこ とにした。基準化した年最小 30、60、90 日間 PI の経年 変化をそれぞれ 図-5a)、b)、c）に示す。

図-4、図-5 ともに、用いた史料によって結果が大き く異なる年が見受けられ、渴水規模について正確な判断 をするためには 2 つ以上の記録を用いて比較検証する必 要があることがわかる。本研究では記録が欠落していた り、単一の記録しか得られない期間もあり資料の量は必 ずしも十分とはいえないが、図-4、図-5に共通して渴 水傾向が顕著な時期 (複数の記録で検証できるもの) を 抽出すると、1770 年前後、1845 年頃、1855 年頃、1910 年頃、等があげられる。年最大連続「小雨」以下日数、 基淮化年最小 60 日間 PI それぞれの指標で抽出した上位 20 の渴水事例を 表-1 に示す。

一方、古文書等には琵琶湖地域で大旱䰠のあった年と して、1770 71、1832 33、1843〜44、1853、1855、 1892 年等が記録されている。1770 年 (明和 7) は 6 月下 旬頃から旱天が続き、翌年 1 月までに湖水は「常水より 壹丈六尺ひき」 ${ }^{6)}$ 、「百年以来之渴水」 ${ }^{3)}$ であったとある。
翌 1771 年も 6 月頃から「土用迄照込」 ${ }^{6)}$ た。1853 年 (嘉 永 6)は 6 月末に大雨が数日続いた後日照りとなり、

「百日間雨無し」「地中四五寸カワク」「松七分通リ枯 ル」等様々な記述が見られる7)ことから、前代未聞の大 旱䰠であったことが窥える。他には 1832 年 7 月 14 日〜 8 月 24 日、 1833 年 7 月、 1843 年 7 8 月、 1844 年 8 月 等が見出される ${ }^{7)}$ が、これらの多くは対応する期間が 表-1 中に抽出されており、古記録に残されている歴史 渴水の規模がある程度定量的に評価されたといえる。

\section{4. おわりに}

琵琶湖流域では、天候記録の他、不完全ながら江戸時 代中期以降は湖水位の記録を得ることができ、この水位 データと天候記録から、流入一貯留一流出の連続関係を 利用して降水量を逆算する手法が考案されている ${ }^{8)}$ 。今 後はこれら湖水位の記録も利用し、渴水規模をより客観 的に評価する手法について検討したい。また、今後とも 古日記の蒐集活動を続けて天候データを蓄積し、基礎 データとしての質的向上を図っていきたい。

謝辞 : 近江八幡市立資料館、滋賀県立図書館、滋賀大学 経済学部附属史料館、彦根市立図書館、水口町立歴史民 俗資料館には、古日記の調査に際して便宜を図っていた だいた。また、名古屋工業大学工学部学生 (当時) 市川 篤励、井上貴洋、西條真紀、佐藤大輔、田中邦彦、柳澤 将道の各氏、同大学院生 井嶋康二氏、及び井嶋美律江、 甲村真理、田中昭生の各氏には、天候記録の収集整理に 際し多くの協力をいただいた。記して謝意を表す。なお 本研究は、(財)クリタ水・環境科学振興財団、(財)河川 環境管理財団 河川整備基金の助成を受けて実施された。

\section{参考文献}

1) 江南良三 : 近江八幡人物伝, 近江八幡市郷土史会, pp.84-113, 128-130, 1981.

2) 山村日記を読む会 : 近江国水口藩大庄屋山村氏諸事書留 第 一冊・文政五年, 水口町立歴史民俗資料館, pp.1-8, 2000.

3) 琵琶湖の水位変動に関する記録の調査研究業務調査報告書, 近畿地方建設局琵琶湖工事事務所・水資源開発公団関西支 社・滋賀県地方史研究家連絡会, 1988.

4) 滋賀県の気象 彦根地方気象台創立 100 周年記念, 彦根地方 気象台, 1993.

5) 吉村稔 : 古気候の復元と歴史天候データベース, 地学雑誌, 102 (2), pp.131-143, 1993.

6) 大橋金造編 : 近江神崎郡志稿 下巻, 滋賀縣神崎郡教育會, pp.858-874, 1928.

7) 近江愛智郡誌 卷三, 滋賀縣愛智郡教育會, pp.741-765, 1929.

8) 庄建治朗・長尾正志・富永晃宏 : 古日記天候記録を用いた琵 琶湖歴史洪水の復元, 土木学会論文集, 655, pp.15-25, 2000.

(2001. 10.1受付) 